\title{
Cultural Appropriation of Polynesian Portrayed In Moana Movie
}

\author{
Nurul Fatha \\ English Literature Department \\ Universitas Muhammadiyah Gorontalo \\ Indonesia \\ nurulftha11@gmail.com \\ Rudiyanto A. Manaku \\ English Literature Department \\ Universitas Muhammadiyah Gorontalo \\ Indonesia
}

\author{
Maryam Adam \\ English Literature Department \\ Universitas Muhammadiyah Gorontalo \\ Indonesia \\ Sesar Tangkilisan \\ English Literature Department \\ Universitas Muhammadiyah Gorontalo \\ Indonesia
}

Citation: Fatha, N., Adam, M., Manaku, R. A., \& Tangkilisan, S. (2021). Cultural appropriation of polynesian portrayed in Moana movie. Notion: Journal of Linguistics, Literature, and Culture Vol 3(2), p. 92-98. http://doi.org/notion.v3i2.4885

\section{Article Info}

\section{Article History}

- Article Received September $20^{\text {th }}, 2021$

- Article Accepted November $2^{\text {nd }}, 2021$

\section{Keywords}

Cultural appropriation Polynesian Cultural exploitation Film

\section{ABSTRACT}

This research aims to identify and describe cultural appropriation that were found in Moana. Cultural appropriation is one of the negative actions that can harm one culture. This action generally occurs due to a lack of understanding and appreciation of a culture. Based on Rogers[6] cultural appropriation as the use of a culture's symbols, artifacts, genres, rituals, or technologies by members of another culture, is inescapable when cultures come into contact, including virtual or representational contact. Rogers also divided cultural appropriation into four types, there are cultural exchange, cultural dominance, cultural exploitation, and transculturation. Based on Rogers theory above, cultural appropriation that were found in Moana is cultural exploitation. This research was used Qualitative descriptive method. The source data of this research are from "Moana" by Ron Clements and John Musker. This movie was released in 2016 with 113 minutes duration. This analysis shows there are four points of cultural appropriation that were found in "Moana". Firstly, depiction figure of "Maui", a demigod figure illustrated very different from the original form in the movie Moana. Secondly, depiction of Kakamora people. Thirdly, depiction of the cliché coconuts. Fourthly, Disney removing Maui's family out of the tale. This leads to deviations in views towards the representatives of the population and Polynesian beliefs. 


\section{Fatha, N., Adam, M., Manaku, R. A., \& Tangkilisan, S. Cultural Appropriation of Polynesian Portrayed in Moana Movie}

\section{INTRODUCTION}

Culture cannot be saperated from human life. Culture is the outcome of collective life of people [4]. Culture will be a unified pattern of belief, knowledge and human behavior. One-way humans describe the culture is through literature. Literature is also stated that the term literature seems best if we limit it to the art of literature, i.e., imaginative literature[9]. Literature also generated by the imagination of the author. The interaction between culture and literature is due to involvement of culture in different area like tradition thoughts, and human perspectives and in this process the literature acts as a powerful instrument. In fact, this interaction both improve the culture and literature sublimity. Human being needs to both literature and cultural values which are the outcomes of their views. Literature is not just a document of facts; it is not just a collection of real events although it may happen in real life. Literature can create its own world as a product of infinite imagination. Literature is one of the ways humans present human culture and life. Literature can also be shown through various types of media such as audio, audio-visual, oral and so on. It is part of cultural expression because it conveys the beliefs of human knowledge and behavior. In addition, we can see that literature is a reflection of a culture that portraying people's opinions, dreams and ideas in the most imaginary and creative way. So, we can learn and understand the culture in literary works.

In daily life we enjoyed some literary works such as us film, song, poetry and prose. Film is one of the literary works that has several genres such as romance, thriller, horror and documenter. The story adapted from novels, books, and many other text literature and formed in to scenario and be re- written into the films script or movie script[1]. Movie or film is a term that encompassed individual motion pictures, the field of movie as an art form, and the motion pictures industry. Films can be produced through adaptations of a country's native culture, race or ethnicity. One of the films that adapts and depicts the culture is Moana, Disney's animation directed by Ron Clements and John Musker.

Moana is an animated film produced by Walt Disney Animation Studios and a 3D computer- animated music adventure film. Directed by Ron Climents and John Musker, the film features the voices of Auli'I Cravalho as Moana, Dwayne Johnson as Maui, Temuere Morrinson as Tui (Moana's father), and Rachel House as Tala's grandmother. In the film, Moana is born and grows as a potential successor to the chieftain on Motonui island and will soon succeed her father, Tui. People on the island of Motonui live by the sea but they have not sailed far any longer because it has been bounded by coral. According to Moana's father, there are many bad things that will happen if you pass through the reef. Moana's story is also resolved because of her curiosity to explore the ocean and see exactly what mystery lies behind the coral.

Reported from IMDB (Internet Movie Database) an online database of information about movies, television shows and productions, that Moana got an average rating of $7.6 / 10$ out of 287 thousand people who participated in the ratings and earned 645 million USD from Disney's total revenue since the release of the film in other words Moana is the film after Frozen which was the largest successful film in the history of Disney cinema.

Indirectly it can be said that literature and culture have a close relationship, the depiction of a culture displayed through literary works must be accurate and does not contain elements of cultural appropriation. Cultural appropriation is particularly controversial since, in the contemporary world, individuals from rich and powerful majority cultures often appropriate from disadvantaged indigenous and minority cultures[10]. Cultural appropriation is profitable[7]. Cultural appropriation is an act that takes or steals culture from minority groups for personal gain. Before going into further what cultural appropriation is, it's a good idea to review the meaning of each word in the phrase. As we know, culture always refers to a group of people who are divided based on their religion, ethnicity, geography and social environment. Appropriation is the act of taking something that is not his own and often refers to the act of exchange that occurs when the dominant tribe or group borrows and even takes something from a minority group and then is exploited or oppressed. Based on Rogers[6] cultural appropriation as the use of a 
culture's symbols, artifacts, genres, rituals, or technologies by members of another culture, is inescapable when cultures come into contact, including virtual or representational contact. Another definition from Cambridge Dictionary, cultural appropriation is the act of taking or using things from a culture that is not your own, especially without showing that understand or respect this culture. Ironically, Cultural appropriation is harmful because it is an extension of centuries of racism, genocide, and oppression. Cultural appropriation treats all aspects of marginalized cultures (also known as targets of oppression) as free for the taking[7].

Many argue that cultural appropriation is not a form of appreciation, but as a form of deprivation of another culture for personal or group interests. In fact, many are less aware of this and then make creations from a culture and unknowingly do the deprivation or exploitation of the culture. Many aspects can be used as objects of cultural appropriation for example, artifact, symbols, clothing, music, language, tattoos and others.

From the above understanding can be interpreted that cultural appropriation is a negative action and will bring harm to the minority who are the subject of this action. Therefore, the author is interested in analyzing the issue of cultural appropriation through Moana film whether there is a practice of cultural appropriation conducted by Disney and describe what forms of cultural appropriation through Moana.

This research is based on Roger's theory. He divided cultural appropriation into four types there are cultural exchange, cultural dominance, cultural exploitation, and transculturation (Rogers, 2006).

1. Culture exploitation is the appropriation of element of a subordinated cultural by a dominant culture without substantive reciprocity, permission, compensation, understanding, or appreciation.

2. Cultural dominance: the use of elements of a dominant culture by members of a sub ordinated culture in a context in which the dominant culture has been imposed onto the subordinated culture, including appropriations that enact resistance.
3. Cultural exchange: the reciprocal exchange of symbols, artifacts, rituals, genres, and/or technologies between cultures with roughly equal levels of power.

4. Transculturation: cultural element created from and/or by multiple cultures, such that identification of a single originating culture is problematic, for example, multiple cultural appropriations structured in the dynamics of globalization and transnational capitalism creating hybrid forms.

In addition to Roger's theory above, the researchers limit this research only on one type of cultural appropriation that is cultural exploitation for any element of that culture that is appropriated. This theory also can be used to make it easier for the writers and readers to focus on what kind of cultural appropriation is contained in Moana.

\section{METHODOLOGY}

For this research, the writer used descriptive qualitative method. The goal of qualitative descriptive studies is a comprehensive summarization, in everyday terms, of specific events experienced by individuals or groups of individuals. The goal of descriptive research is to describe of phenomenon and it is characteristics. This research is more concerned with what rather than how or why something has happened[2]. In other hand, Creswell[8] explains that qualitative research is an approach for exploring and understanding the meaning individuals or groups ascribe to a social human problem. Qualitative research, however, is more holistic and often involves a rich collection of data from various sources to gain a deeper understanding of individual participants, including their opinions, perspectives, and attitudes[5]. In addition, qualitative method aims to guide the researcher in order to be able to focus on the appropriate facts in the field using data analysis. For support this research, the source of data is from articles about Polynesian culture and Moana movie by Ron Clements and John Musker. This movie was released in 2016 with 113 minutes duration.

Technique of collecting data is a systematic procedure in collecting data of the study[3]. After the data has been collected, researchers conducted 


\section{Fatha, N., Adam, M., Manaku, R. A., \& Tangkilisan, S. Cultural Appropriation of Polynesian Portrayed in Moana Movie}

research through several steps: 1) understanding about cultural appropriation by reading some definition and theory that is proposed by experts, 2) collecting and reading the data of Polynesian culture, 3) watching the entire Moana's movie, 4) identifying all of the cultural appropriation problem of the movie, 5) write down the data, 6) listing out all of the problem.

After collecting data, the researcher make document and will interpret the result of the analyzing to make conclusion. The steps in analyzing data are: 1) the researchers describe the cultural appropriation that were found in Moana, based on Rogers theory[6], kind of cultural appropriation that were found in Moana is cultural exploitation, 2) the researcher making conclusion all the analysis about cultural appropriation in Moana.

\section{RESULT AND DISCUSSION}

In this matter, the author discovered an interesting fact, which Disney claimed that they had done several years of research before producing Moana. Precisely Disney deployed an observation team to conduct research three times in the space of three years. The first observations were made in October 2011 to examine the geographical background of the islands of Fiji, Bora-Bora, Samoa and Tahiti to obtain an accurate picture of the location. This was followed by research on culture and music in March 2014 and the last observation in November 2014 for the final research.

Unfortunately, the reality is that Disney clearly ignores the accuracy of the native culture of Polynesian tribes. Evident from some of the things found in this film contains some elements that are very sensitive to the tribe. This leads to deviations in views towards the representatives of the population and their beliefs.

After analyzing data, the writer found four cultural appropriations contained in Moana's film with a degree of difference in depictions of culture that are far from the original culture.

1. Depiction figure of "Maui", a demigod figure illustrated very different from the original form in the movie Moana.

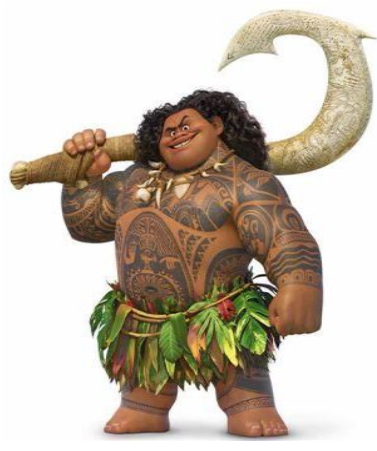

Picture 1. Figure of Maui

According to Polynesian mythology, Maui was a demigod and was a son of the god Tangaroa. According to the mythology, he is who created the Hawaiian island, which is now home to Polynesians. From mythology is also what makes Maui respected even no doubt he was also worshiped by some people in the Polynesian islands. Maui's real-life figure and Maui's portrayal in the movie "Moana" are very different. For example, in physical depictions, Polynesian mythology tells of Maui who has a stocky posture, is fit and still the age of adolescence and has intelligence and wisdom. But in this film Maui portrayed as someone who is fat, too black, fat and looks old. Another example is Maui's nature, which is described as a fool because he often speaks with his own tattoos.

As part of the Polynesian indigenous culture, they have always had similarities as well as specific structures for patterns and colors in the application and depiction of tattoos on their bodies. The tattoos they apply have an important meaning as a form of communication. The resulting tattoos also indicate rank, family pedigree and social status in society. Interestingly, the tattoos found on each individual describe hope and prayer for protection, strength, balance, health and energy for life. Not only patterns and colors, the placement of tattoos is also very influential and gives special meaning to the user, such as tattoos on the hands and arms signify creativity and results. While the tattoo on the head reflects the meaning of knowledge, spirituality, and intuition. Back to the fact that Disney portrayed Maui as a fool for talking too often on his tattoos, for Polynesian residents, Maui has a thoughtful and intelligent nature. 
Ironically, based on data from the WHO in 2014, that the islands of Polynesia are included in the list of the highest obesity rates. That makes people's views on Disney's depiction of obesity in Maui the right thing to do. On the other hand, The Maui figure by Disney was created before who's 2014 research. This is an affront to the beliefs of Polynesian tribes that have been guarded for centuries and led to most Polynesian families banning their children from watching the film.

2. Depiction of Kakamora People

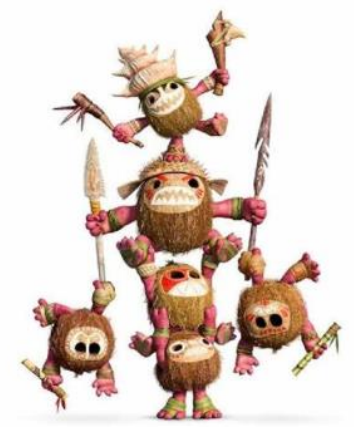

Picture 2. Kakamora People

Based on pacific cultural history, Kakamora is a legendary tribe from the Solomon Islands who live in the forest and hide in caves. Kakamora people have a very short body shape, only about six inches $(15 \mathrm{~cm})$, using a head covering of coconuts and have sharp and sharp nails. They are known to some as evil and dangerous creatures because they often attack and eat humans. In another source said that Kakamora only attacked men.

All of the above are, of course, very different from the Disney depictions contained in Moana. In this film, Kakamora tribe is depicted as coconut that has hands and feet and has iron armor from coconut. As Moana said when she first saw Kakamora it was "they are kinda cute" but her expression changed after Kakamora crossed their faces and pulled out a sword. From the scene it can be assumed that the Kakamora is not creepy and looks funny. Plus, when they force themselves to look creepy by scribbling their faces. This could change people's view of the creepy and middle-aged Kakamora, making them less wary when visiting the Solomon Islands. Because Kakamora are not friendly with humans, as a result they can attack and wildly eat children and tourists.
In this film too, Kakamora looks like a stupid pirate driving a big, dirty ship, with lots of coconut trees on board. It can be concluded that Kakamora looks like a bunch of homeless punks, living off spoils and just tossing over the ocean with no apparent purpose. This depiction is certainly different from the Kakamora people who settled on an island and lived off the forest.

Disney's actions in this depiction of the Kakamora tribe are clearly very much different from the original history of pacific culture. Indirectly, Disney does not value the indigenous culture and beliefs that exist in the Pacific Region.

\section{Depiction of cliché coconuts}

Coconut is known as one of the important cultural components for Polynesian people. They consider that coconut is one of the sacred fruits and has been around since the time of their ancestors. Coconut is already famous for its many properties and uses so that not only Polynesian people who feel its usefulness but also the whole world. The use of coconut that we have often felt is nutrients from coconut meat that is abundant such as protein, fiber, and vitamin $\mathrm{C}$ for daily needs. There are many other uses found in coconuts including oil, coconut skin, and leaves.

In this case, Disney overreacted and made a bad impression on the use of coconut elements, coupled with the fact that coconuts were an important component of the pacific island culture that became a major comedic element in the 1960s American television series "Giligan's Island". This led to a comedy stereotype as well as an insult to coconuts that became one of the cultural elements of Polynesian tribes.

The overuse in the use of coconut elements is very clear when Disney depicts the Motunui community dancing, where in the lyrics of their song, coconut fruit is the only staple food, and coconut becomes the only superior commodity on the island. In this depiction, Disney seems to shape the audience's mindset that Polynesian people or people living on the coast only rely on coconut as their staple food.

The depiction of the coconut element that looks excessive is also shown by Disney in the depiction of 


\section{Fatha, N., Adam, M., Manaku, R. A., \& Tangkilisan, S. Cultural Appropriation of Polynesian Portrayed in Moana Movie}

the Kakamora tribe, where Kakamora looks like a coconut that has grown its hands. Not only there, the boat used by the Kakamora tribe is not spared from the excessive use of coconut elements, where the boat is made of piles of coconuts that are in one, moreover there are some coconut trees that are growing as in the land.

This led researchers to conclude that Disney was excessive and bad at using coconut elements in Moana. Thus, making the world's view of Polynesian society can change and harm the Polynesian community itself.

\section{Disney removing Maui's family out of the tale}

In Polynesian history, Maui, is a son of the couple 'Akalana and Hina-a-ke-ahi (Moon Goddess), an ancient cultural hero and chieftain born with demigod blood has inspired centuries of his deeds. Like when he held back the sun at the request of his mother who struggled when he wanted to dry clothes from the skin. This resulted in the movement of the sun to be slow, so that the good impact can be felt by humans until now. There was also Maui when he tricked his brothers into going fishing big fish, but it turned out that he used the energy of his brothers not to fish big fish but to pull the islands from the bottom of the sea. These islands are home to Polynesians until now.

From the history that circulated in Polynesian society, Maui always lived with her family, as well as the actions she did not escape the intervention of her family. As in the action above when he holds the sun, he uses a rope made of his sister's hair.

According to the film, Disney describes Maui as a man born to a mortal human couple. His parents felt that Maui would only be a burden, and had no effect on life, so he was banished to the sea and wished Maui to die. However, he was saved by the gods and took care of him and taught him science, and the gods also provided supernatural abilities, immortality, and magic hooks.

Some Maui deeds such as holding the sun, fishing the island, holding the wind, taking fire from the bottom of the earth, until he took the fiti (Heart of Life) heart just for the sake of getting recognition, sympathy and love from humans that he did not get from his parents. While in the original history, Maui did not do its action for mankind but rather was the result of his nosy deeds, whose impact was felt by Polynesian society to date.

This depiction of Disney is certainly very opposite, where Maui is also told as an orphan while in its original history, the role of the family of both parents and siblings is very important for the ins and outs of Maui life story. Indirectly, the removal of this element of the Maui family, can lead to deviations in the original history and beliefs of Polynesian tribes.

\section{CONCLUSION}

Culture conveys the beliefs of human knowledge and behavior. Through literary works, people are able to tell stories of a variety cultures. One of the literary works which can be means to tell the culture is through films. One of the films that adapts and depicts the culture is Moana, Disney's animation directed by Ron Clements and John Musker.

Disney claimed that they had done several years of research before producing Moana. Disney deployed an observation team to conduct research three times in the space of three years. Nevertheless, the writer found four cultural appropriations contained in Moana's film with a degree of difference in depictions of culture that are far from the original. First, construct people understanding about depiction figure of "Maui", the demigod of Polynesian that different from the original story. In this film Maui is portrayed as someone who is fat, too black and looks old. Meanwhile, the real Maui has a stocky posture, is fit and still the age of adolescence.

Second, changing people's view of the creepy of the Kakamora tribe. Kakamora is a legendary tribe from the Solomon Islands who known as evil and dangerous creatures because they often attack and eat humans. Besides, in the movie Kakamora are shown as coconut that has hands and feet which makes them look so cute. That way, people become less alert when visiting Solomon Islands.

Third, Disney overreacted and made a bad impression on the use of coconuts element, because coconut is one of the important cultural components for Polynesian and has been around since the time of their ancestors. In the 1960s American television 
series "Giligan's Island", coconut was a major comedic element in the pacific island culture. This led to a comedy stereotype as well as an insult to coconuts that became one of the cultural elements of Polynesian tribes.

Fourth, Disney removed the family of Maui. Maui is told as an orphan, but in the history he always with his family until the rest of his life. The role of his family is very important for the ins and outs of Maui's life. So, the removal of the Maui's family, can lead to deviations in the original history and beliefs of Polynesian tribes.

From the explanations that have been presented, the author reiterates how important it is to learn about cultural appropriation not only in films but in all aspects, in order to know and be able to distinguish the cultural values in life.

\section{REFERENCES}

[1] Arif, M. Z., \& Kuswandari, A. (2019). An analysis of moral value in "the Kite Runner" Film (Based on Its Main Characters). Professional Journal of English Education, 2(4), 564-574.

[2] Bennett, N., Borg, W. R., \& Gall, M. D. (1984). Educational Research: An Introduction. British Journal of Educational Studies (Vol. 32, Issue 3, p. 274). https://doi.org/10.2307/3121583

[3] Elmusharaf, K. (2018). Introduction to training course in research.

[4] Hesaraki, R. M. (2014). Literature and culture: both interaction and effectiveness Mohammad. 4(3), 1376-1378.

[5] Nassaji, H. (2015). Qualitative and descriptive research: Data type versus data analysis. Language Teaching Research, 19(2), 129-132. https://doi.org/10.1177/1362168815572747

[6] Rogers, R. A. (2006). From cultural exchange to transculturation: A review and reconceptualization of cultural appropriation. Communication Theory, 16(4), 474-503. https://doi.org/10.1111/j.14682885.2006.00277.x

[7] Stall-Meadows, C. (2018). Cultural Appreciation or Cultural Appropriation. Bloomsbury Fashion
Business

Cases.

https://doi.org/10.5040/9781474208765.0014

[8] Creswell, J. W. (2014). Research Design (Vicki knight (ed.), (4 ${ }^{\text {th }}$ ed). Sage publication.

[9] Wellek, R., \& Warren, A. (1956). Wellek-Theory of Lit.pdf.

[10]Young, J. O. (2008). Cultural Appropriation and the Arts. Cultural Appropriation and the Arts, 1-168. https://doi.org/10.1002/9780470694190 